\title{
[3-[(1-Methylpiperidin-4-yl) methyl] arylsulfonyl]-1H-indoles: Synthesis, SAR and biological evaluation as a novel class of 5-HT 6 Receptor Antagonists
}

\author{
RAMAKRISHNA V S NIROGI ${ }^{\mathrm{a}, *}$, RAJESH KUMAR BADANGE ${ }^{\mathrm{a}, \mathrm{b}}$, \\ KIRAN KUMAR KANDUKURI ${ }^{\mathrm{a}}$ and MUKKANTI KHAGGA ${ }^{\mathrm{b}}$ \\ ${ }^{a}$ Discovery Research, Suven Life Sciences Limited, Serene Chambers, Road 5, Avenue 7, \\ Banjara Hills, Hyderabad 500 034, India \\ ${ }^{\mathrm{b}}$ Institute of Science and Technology, JNTU Hyderabad, Kukatpally, Hyderabad 500 085, India \\ e-mail:nvsrk@suven.com
}

MS received 26 May 2014; revised 26 July 2014; accepted 28 July 2014

\begin{abstract}
In continuation to our efforts to develop better treatment options for cognitive decline, we have been focussing on 5- $\mathrm{HT}_{6}$ receptor $\left(5-\mathrm{HT}_{6} \mathrm{R}\right)$ antagonists, which are known to be involved in improving $\operatorname{cog}$ nitive function in numerous animal models. In this paper, we report a novel series of [3-[(1-Methylpiperidin4-yl) methyl] arylsulfonyl]-1 $H$-indole derivatives as potent and selective $5-\mathrm{HT}_{6} \mathrm{R}$ antagonists. The lead compound from this series shows potent in vitro binding affinity, functional antagonistic activity at $5-\mathrm{HT}_{6} \mathrm{R}$, good pharmacokinetic profile, excellent selectivity and no Cytochrome P450 liabilities.
\end{abstract}

Keywords. [3-[(1-Methylpiperidin-4-yl) methyl] arylsulfonyl]-1H-indoles; 5-HT ${ }_{6} \mathrm{R}$ antagonists; cognitive impairment; structure activity relationship; cross selectivity; pharmacokinetic profile.

\section{Introduction}

Cognitive decline is a defining symptom of many severe neurological disorders, viz., Alzheimer's disease (AD), Schizophrenia, Parkinson's disease (PD), etc. ${ }^{1}$ The current options to treat cognitive symptoms associated with neurological disorders mentioned above include drugs like Donepezil ${ }^{2}$ and Memantine. ${ }^{3}$ These drugs have limited efficacy and poor tolerability. ${ }^{4}$ This poses a great need for the discovery of new drugs for the treatment of cognition through a novel mechanism of action, and thus 5-hydroxytryptamine-6-receptor $\left(5-\mathrm{HT}_{6} \mathrm{R}\right)$ has attracted a lot of attention in the recent past. $5-\mathrm{HT}_{6} \mathrm{R}$ belongs to serotonin super family and they are exclusively located in those regions in the brain that are associated with learning and memory. ${ }^{5}$ Studies have found that known $5-\mathrm{HT}_{6} \mathrm{R}$ antagonists have selectively increased glutamate and acetylcholine levels in brain, a phenomenon associated with learning and memory. ${ }^{6}$ The exclusive Central Nervous System (CNS) location and high affinity of several psychiatric drugs towards this receptor suggests that antagonism of $5-\mathrm{HT}_{6} \mathrm{R}$ could potentially provide effective treatment towards cognitive dysfunction associated with $\mathrm{AD}{ }^{7}$

*For correspondence
SB-742457, $\mathbf{A}^{8}$ and Lu AE58054, $\mathbf{B}^{9}$ are the two advanced stage $5-\mathrm{HT}_{6} \mathrm{R}$ antagonists that have completed phase II clinical trials. Modification in the side chain of $N$-arylsulfonyl tryptamine, for e.g., MS-245, $\mathbf{C},{ }^{10}$ a known $5-\mathrm{HT}_{6} \mathrm{R}$ antagonist has led to the discovery of structurally diverse compounds as depicted by structures $\mathbf{D}^{11}$ (reported by our research group) and $\mathbf{E}^{12}$ which are potent $5-\mathrm{HT}_{6} \mathrm{R}$ antagonists. In general, these compounds are characterized by having the cyclic amine moiety on indole nucleus. We were interested in evaluating the effect of migrating the cyclic amine moiety from indole central core to arylsulfonyl group on indole, as the latter type of compounds are not reported in the literature. Thus we have designed a new series, i.e., Compounds I, which align with pharmacophoric model of $5-\mathrm{HT}_{6} \mathrm{R}^{13}$ and we expect them to be potent 5- $\mathrm{HT}_{6} \mathrm{R}$ ligands. In this paper, we report synthesis and in vitro preliminary biological data of Compounds I (figure 1).

\section{Experimental}

\subsection{General information}

All the reagents and chemicals used were of 'reagent grade.' Thin layer chromatography (TLC) was performed on Merck silica gel $60 \mathrm{~F}_{254}$ plates, and spots 
<smiles>O=S(=O)(c1ccccc1)c1cnc2c(N3CCNCC3)cccc2c1</smiles>

SB-742457,A

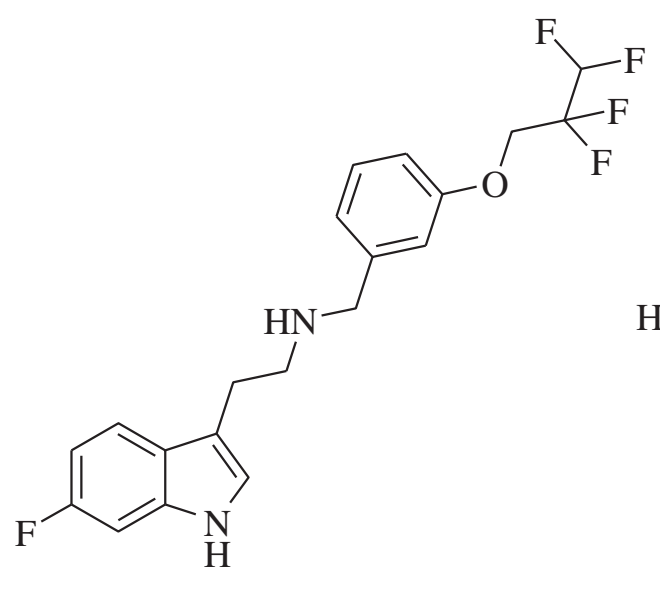

Lu AE58054, B

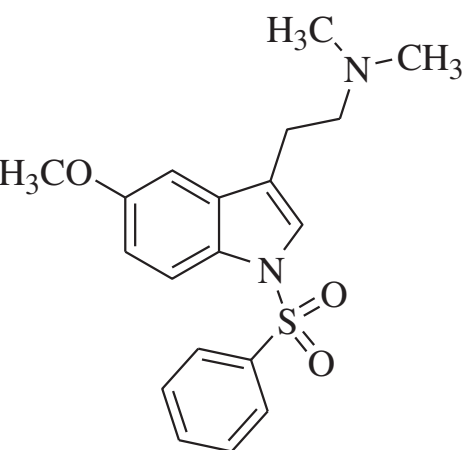

MS-245, C<smiles>[R]Oc1ccc2c(c1)c(C1CCN(C)C1)cn2S(=O)(=O)c1ccc(C(C)C)cc1</smiles>

D

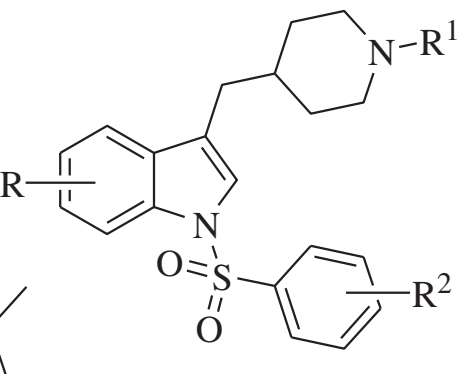

$\mathbf{E}$

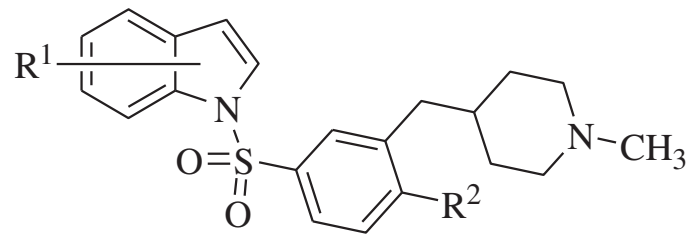

Compounds I

Figure 1. Reported 5-HT 6 R antagonists.

were visualized in UV light $(254 \mathrm{~nm})$ and/or iodine. Purification of compounds was accomplished by column chromatography performed using 60-120 mesh silica gel and executed under nitrogen pressure (flash chromatography) conditions. Purity of the final compounds (>95\%) was established using Agilent 1100 high-performance liquid chromatography (HPLC) system. All the mentioned yields refer to isolated pure products. Infrared spectra were recorded on $\mathrm{KBr}$ disk and in solid state using Perkin-Elmer model 1600 FT-IR spectrophotometer (Perkin-Elmer, Norwalk, CT, USA). ${ }^{1} \mathrm{H}$ NMR spectra were obtained on a Bruker NMR spectrometer (Fallanden, Switzerland) at $400 \mathrm{MHz}$. Deuterated reagents were used as solvents and were commercially procured. Tetramethylsilane (TMS) was used as an internal standard, chemical shift values are expressed in parts per million $(\delta)$ and coupling constants are expressed in Hz. Electrospray ionization mass spectra were recorded on a API 4000 triple quadrupole instrument (MDS-SCIEX, Concord, Ontario, Canada).

Indole derivatives were either commercially procured or synthesized as per literature methods. ${ }^{14}$ Substituted benzoic acids were reacted with chlorosulfonic acid to afford substituted 3-carboxybenzenesulfonyl chlorides 2a-c. Synthesis of targeted compounds 9a-o was achieved as depicted in scheme 1. Substituted indoles $\mathbf{1}$ were reacted with substituted sulfonyl chlorides $\mathbf{2 a -}$ c in presence of sodium hydride to obtain intermediates 3a-o. The carboxylic acid group of intermediates 3a-o was reduced with lithium aluminium hydride in THF to obtain benzyl alcohol derivatives 4a-o. Reaction of 4a-o with phosphorus tribromide gave the benzyl bromide derivatives 5a-o. The intermediates 5ao on reaction with triphenyl phosphine gave the phosphonium salts $\mathbf{6 a - 0}$, which on further reaction with 1-methylpiperidone under Wittig reaction conditions gave the alkene intermediates $\mathbf{8 a - 0}$. The $\mathrm{Pd} / \mathrm{C}$ catalyzed hydrogenation of intermediates 8a-o afforded the targeted compounds 9a-o.

\subsection{Synthesis of arylsulfonyl chlorides: General procedure for the preparation of 3-Chlorosulfo- nylbenzoic acid $\left(2 a, R^{2}=H\right)$}

Benzoic acid (5 g, $40.9 \mathrm{mmol}$ ) was added in portions to chlorosulfonic acid (14.3 g, $122.9 \mathrm{mmol})$ under stirring at $5-10^{\circ} \mathrm{C}$ and then stirred at $110^{\circ} \mathrm{C}$ for $2 \mathrm{~h}$. The reaction mixture was cooled to room temperature, poured on to 
<smiles>[R]c1ccc(S(=O)(=O)[R16]([R16])([R15])[H])cc1C(=O)O</smiles>

1

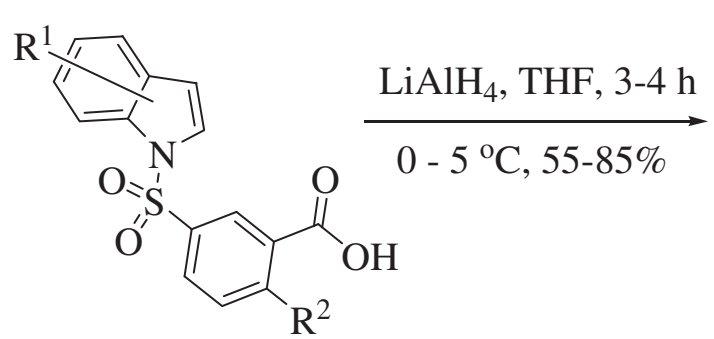

3a-o

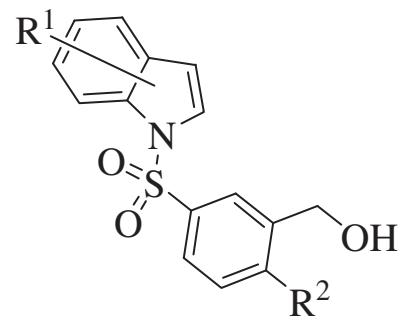

4a-o<smiles>[R4]c1ccc2ccn(S(=O)(=O)c3ccc([R])c(CBr)c3)c2c1</smiles>

5a-0

6a-o

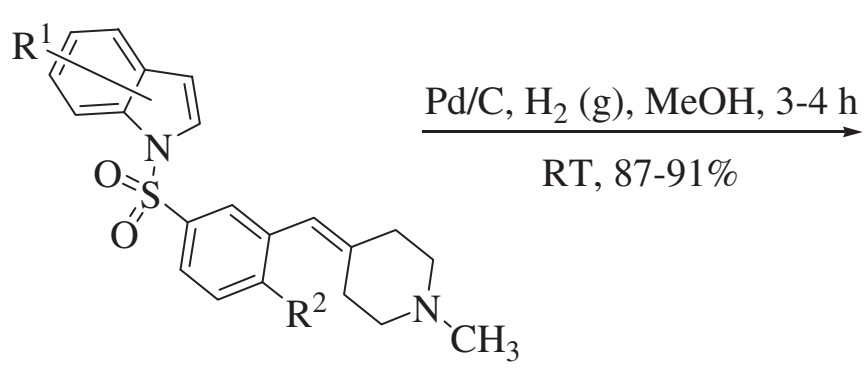

8a-o<smiles></smiles>

9a-0

Scheme 1. Synthesis of [3-[(1-Methylpiperidin-4-yl) methyl] arylsulfonyl]-1H-indoles 9a-o.

crushed ice $(\sim 100 \mathrm{~g})$ under stirring during which solids precipitated. These solids were filtered, extracted with ethyl acetate $(150 \mathrm{~mL})$, dried over anhydrous $\mathrm{Na}_{2} \mathrm{SO}_{4}$, and concentrated under reduced pressure to obtain the title compound as solid mass (5.4 g, 60\% yield). IR $\left(\mathrm{cm}^{-1}\right.$ ): 3410 (broad, due to $-\mathrm{OH}$ stretching vibrations of $-\mathrm{COOH}$ group) and $\sim 1313$ and 1182 (sharp, strong, due to asymmetric and symmetric stretching vibrations of $-\mathrm{SO}_{2}$ group respectively). ${ }^{1} \mathrm{H}$ NMR $\left(\mathrm{CDCl}_{3}, 400\right.$ $\mathrm{MHz}) \delta: 8.78(1 \mathrm{H}, \mathrm{t}, J=1.60 \mathrm{~Hz}), 8.48(1 \mathrm{H}, \mathrm{d}, J=$ $8.0 \mathrm{~Hz}), 8.28-8.31(1 \mathrm{H}, \mathrm{dd}, J=8.0,1.6 \mathrm{~Hz}), 7.80(1 \mathrm{H}$, $\mathrm{t}, J=8.0 \mathrm{~Hz})$. ESI mass: $\mathrm{m} / \mathrm{e} 219.1(\mathrm{M}-\mathrm{H})^{+}$.

\subsection{General procedure for the preparation} of 3-Methyl-1-(3-carboxybenzenesulfonyl)-1H-indole $\left(3 m, R^{1}=3-\mathrm{CH}_{3}, \mathrm{R}^{2}=\mathrm{H}\right)$

A solution of 3-methyl-1 $H$-indole $(1 \mathrm{~g}, 7.6 \mathrm{mmol})$ in dry THF was added to a stirred suspension of $\mathrm{NaH}$
(0.91 g, $22.9 \mathrm{mmol}, 60 \%$ oil suspension) at $25-30^{\circ} \mathrm{C}$ under stirring and maintained for $30 \mathrm{~min}$. Then a solution of 3-chlorosulfonyl benzoic acid (1.85 g, 8.39 $\mathrm{mmol}$ ) in dry THF was added to the above mixture at room temperature and stirred for $4 \mathrm{~h}$. The reaction mixture was then poured on to water $(50 \mathrm{~mL})$, acidified with dil. $\mathrm{HCl}$ and extracted with ethyl acetate $(50 \mathrm{~mL}$ $\times 3$ ). The organic extracts were combined, dried over anhydrous $\mathrm{Na}_{2} \mathrm{SO}_{4}$, and concentrated under reduced pressure. The resultant crude compound was chromatographed $\left(\mathrm{SiO}_{2}, 30: 70\right.$ EtOAc-hexanes as eluent) to afford title compound as solid mass ( $1.51 \mathrm{~g}, 63 \%$ yield). IR $\left(\mathrm{cm}^{-1}\right): 3411(-\mathrm{OH}$ stretching vibrations of $-\mathrm{COOH}$ group), 1679 (stretching vibrations of $-\mathrm{C}=\mathrm{O}$ functional group of carboxylic acid), 1374 and 1154 (asymmetric and symmetric stretching vibrations of $-\mathrm{SO}_{2}$ group respectively). ${ }^{1} \mathrm{H}$ NMR $\left(400 \mathrm{MHz}, \mathrm{DMSO}-d_{6}\right) \delta: 8.35$ $(1 \mathrm{H}, \mathrm{s}), 8.15(2 \mathrm{H}, \mathrm{t}, J=7.42 \mathrm{~Hz}), 7.93(1 \mathrm{H}, \mathrm{d}, J=$ $8.27 \mathrm{~Hz}), 7.68(1 \mathrm{H}, \mathrm{t}, J=7.88 \mathrm{~Hz}), 7.62(1 \mathrm{H}, \mathrm{s}), 7.53$ 
$(1 \mathrm{H}, \mathrm{d}, J=7.74 \mathrm{~Hz}), 7.37(1 \mathrm{H}, \mathrm{t}, J=7.49 \mathrm{~Hz}), 7.27$ $(1 \mathrm{H}, \mathrm{t}, J=7.54 \mathrm{~Hz}), 2.20(3 \mathrm{H}, \mathrm{s})$. ESI mass: m/e 313.9 $(\mathrm{M}-\mathrm{H})^{+}$.

\subsection{General procedure for the preparation} of 3-Methyl-1-(3-hydroxymethyl benzenesulfonyl)lH-indole $\left(4 m, \mathrm{R}^{1}=3-\mathrm{CH}_{3}, \mathrm{R}^{2}=\mathrm{H}\right)$

A solution of $\mathbf{3 m}(1.5 \mathrm{~g}, 4.76 \mathrm{mmol})$ in dry THF (25 $\mathrm{mL}$ ) was added to a stirred suspension of lithium aluminium hydride $(0.54 \mathrm{~g}, 14.3 \mathrm{mmol})$ below $0^{\circ} \mathrm{C}$ and further stirred for $3 \mathrm{~h}$ at this temperature. After completion of the reaction (TLC), ice cold water $(5 \mathrm{~mL})$ was added slowly to the reaction mixture to decompose excess of LAH. The resultant mixture was filtered and the residue was washed with ethyl acetate $(25 \mathrm{~mL} \times 2)$. The filtrate was dried over anhydrous $\mathrm{Na}_{2} \mathrm{SO}_{4}$ and concentrated under reduced pressure. The resultant crude compound was chromatographed $\left(\mathrm{SiO}_{2}, 25: 75\right.$ EtOAchexanes as eluent) to afford title compound as syrupy mass $(1.2 \mathrm{~g}, 84 \%$ yield $)$. IR $\left(\mathrm{cm}^{-1}\right): 3199\left(\mathrm{ArCH}_{2} \mathrm{O}-\mathrm{H}\right.$ stretching vibration), 1371 and 1166 (asymmetric and symmetric stretching vibrations of $-\mathrm{SO}_{2}$ group respectively). ${ }^{1} \mathrm{H}$ NMR $\left(400 \mathrm{MHz}, \mathrm{CDCl}_{3}\right) \delta: 7.98(1 \mathrm{H}, \mathrm{d}, J=$ $8.27 \mathrm{~Hz}), 7.86(1 \mathrm{H}, \mathrm{bs}), 7.77(1 \mathrm{H}, \mathrm{d}, J=7.87 \mathrm{~Hz}), 7.50$ $(1 \mathrm{H}, \mathrm{d}, J=7.63 \mathrm{~Hz}), 7.45(1 \mathrm{H}, \mathrm{d}, J=7.57 \mathrm{~Hz}), 7.39$ $(1 \mathrm{H}, \mathrm{t}, J=7.79 \mathrm{~Hz}), 7.29-7.33(2 \mathrm{H}, \mathrm{m}), 7.23(1 \mathrm{H}, \mathrm{d}$, $J=7.16 \mathrm{~Hz}), 4.68(2 \mathrm{H}, \mathrm{d}, J=5.4 \mathrm{~Hz}), 2.24(3 \mathrm{H}, \mathrm{s})$. ESI mass: $\mathrm{m} / \mathrm{e} 302.2(\mathrm{M}+\mathrm{H})^{+}$.

2.5 General procedure for the preparation of 3Methyl-1-(3-bromomethylbenzenesulfonyl)-1H-indole $\left(5 m, R^{1}=3-\mathrm{CH}_{3}, \mathrm{R}^{2}=\mathrm{H}\right)$

Phosphorus tribromide $(0.16 \mathrm{~mL}, 1.66 \mathrm{mmol})$ was added to a stirred solution of $\mathbf{4 m}(1 \mathrm{~g}, 3.32 \mathrm{mmol})$ in DCM $(20 \mathrm{~mL})$ at $5-10^{\circ} \mathrm{C}$ and then stirred below $10^{\circ} \mathrm{C}$ for further $0.5 \mathrm{~h}$. After completion of the reaction (TLC), the reaction mixture was poured on to cold water $(25 \mathrm{~mL})$. The organic layer was separated, washed with saturated $\mathrm{NaHCO}_{3}$ solution $(10 \mathrm{~mL})$, brine solution $(10 \mathrm{~mL})$, dried over anhydrous $\mathrm{Na}_{2} \mathrm{SO}_{4}$ and concentrated under reduced pressure to obtain title compound as oily mass (1.02 g, 85\% yield). This was used as such for further reaction.

\subsection{General procedure for the preparation of} [3-(3-Methyl-1H-indole-1-sulfonyl) benzyl]-triphenyl phosphonium bromide $\left(6 \mathrm{~m}, \mathrm{R}^{1}=3-\mathrm{CH}_{3}, \mathrm{R}^{2}=\mathrm{H}\right)$

Triphenyl phosphine $(0.72 \mathrm{~g}, 2.74 \mathrm{mmol})$ was added to a stirred solution of $\mathbf{5 m}(1 \mathrm{~g}, 2.74 \mathrm{mmol})$ in acetonitrile $(25 \mathrm{~mL})$ at room temperature. The reaction mixture was then refluxed for $4 \mathrm{~h}$ and then concentrated to obtain a crude compound. The crude compound was triturated with ethyl acetate $(25 \mathrm{~mL})$ and resultant white solids were filtered and dried under vacuum to obtain title compound (1.15 g, 67\% yield). ${ }^{1} \mathrm{H}$ NMR (400 MHz, DMSO- $\left.d_{6}\right) \delta: 7.88(2 \mathrm{H}, \mathrm{t}, J=7.44 \mathrm{~Hz}), 7.81(2 \mathrm{H}, \mathrm{d}$, $J=7.89 \mathrm{~Hz}), 7.55-7.67(15 \mathrm{H}, \mathrm{m}), 7.40(1 \mathrm{H}, \mathrm{t}, J=$ $7.87 \mathrm{~Hz}), 7.18-7.29(4 \mathrm{H}, \mathrm{m}), 5.25(2 \mathrm{H}, \mathrm{d}, J=15.78$ $\mathrm{Hz}), 2.18(3 \mathrm{H}, \mathrm{s})$.

\subsection{General procedure for the preparation of 3-Methyl-1-[3-(1-methylpiperidin-4-ylidene methyl) benzenesulfonyl]-1H-indole \\ $\left(8 m, R^{1}=3-\mathrm{CH}_{3}, R^{2}=\mathrm{H}\right)$}

Sodium hydride $(0.096 \mathrm{~g}, 2.39 \mathrm{mmol}, 60 \%$ oil suspension) was added to a stirred solution of $6 \mathrm{~m}(1 \mathrm{~g}$, $1.59 \mathrm{mmol})$ at room temperature, then heated to $55^{\circ} \mathrm{C}$ and maintained for $1 \mathrm{~h}$. 1-Methyl-4-piperidone $(0.22 \mathrm{~g}$, $1.91 \mathrm{mmol}$ ) was added to the above mixture at room temperature followed by stirring at $60^{\circ} \mathrm{C}$ for $3 \mathrm{~h}$. The reaction mixture was then cooled to room temperature, poured on to water $(50 \mathrm{~mL})$, extracted with ethyl acetate $(50 \mathrm{~mL} \times 4)$. The organic extracts were combined, washed with brine $(50 \mathrm{~mL})$, dried over anhydrous $\mathrm{Na}_{2} \mathrm{SO}_{4}$ and concentrated under reduced pressure. The resultant crude compound was chromatographed $\left(\mathrm{SiO}_{2}\right.$, 2:98 ammonical MeOH:EtOAc as eluent) to afford title compound as syrupy mass $(0.41 \mathrm{~g}, 68 \%$ yield $)$. IR $\left(\mathrm{cm}^{-1}\right)$ : $\sim 3021$ (asymmetric stretching vibrations of $\mathrm{C}=\mathrm{C}$ - functional group), $\sim 1328$ and 1153 (asymmetric and symmetric stretching vibrations of $-\mathrm{SO}_{2}$ group respectively). ${ }^{1} \mathrm{H}$ NMR $\left(400 \mathrm{MHz}, \mathrm{DMSO}-d_{6}\right) \delta: 7.99$ $(1 \mathrm{H}, \mathrm{d}, J=8.23 \mathrm{~Hz}), 7.66-7.69(1 \mathrm{H}, \mathrm{m}), 7.62-7.62$ $(1 \mathrm{H}, \mathrm{s}), 7.46(1 \mathrm{H}, \mathrm{d}, J=7.94 \mathrm{~Hz}), 7.33-7.37(2 \mathrm{H}, \mathrm{m})$, 7.28-7.31 (2H, m), 7.23-7.24 (1H, m), $6.20(1 \mathrm{H}, \mathrm{s})$, $2.49(2 \mathrm{H}, \mathrm{t}, J=5.36 \mathrm{~Hz}), 2.39(2 \mathrm{H}, \mathrm{t}, J=5.60 \mathrm{~Hz})$, $2.31(3 \mathrm{H}, \mathrm{s}), 2.27-2.30(4 \mathrm{H}, \mathrm{m}), 2.24(3 \mathrm{H}, \mathrm{s})$. ESI mass: $\mathrm{m} / \mathrm{e} 381.3(\mathrm{M}+\mathrm{H})^{+}$.

2.8 General procedure for the preparation of 3-Methyl-1-[3-(1-methylpiperidin-4-yl methyl) benzenesulfonyl]-1H-indole $\left(9 m, R^{1}=3-C_{3}\right.$, $\left.R^{2}=H\right)$

A stirred mixture of $\mathbf{8 m}(0.4 \mathrm{~g}, 1.05 \mathrm{mmol})$ and $\mathrm{Pd} / \mathrm{C}$ in methanol was stirred for $4 \mathrm{~h}$ under $\mathrm{H}_{2}(\mathrm{~g})$ bubbling. Then the reaction mixture was filtered and concentrated under reduced pressure. The resultant crude mass was chromatographed $\left(\mathrm{SiO}_{2}, 2: 98\right.$ ammonical $\mathrm{MeOH}: \mathrm{EtOAc}$ as eluent) to afford title compound as solid mass (0.36 g, 90\% yield). IR $\left(\mathrm{cm}^{-1}\right)$ : 2930 (due to $\mathrm{sp}^{3} \mathrm{C}-\mathrm{H}$ stretching vibrations), 1365 and 1171 
(asymmetric and symmetric stretching vibrations of $\mathrm{SO}_{2}$ group respectively). ${ }^{1} \mathrm{H} \mathrm{NMR}\left(400 \mathrm{MHz}, \mathrm{CDCl}_{3}\right) \delta$ : $7.97(1 \mathrm{H}, \mathrm{d}, J=8.24 \mathrm{~Hz}), 7.61-7.66(2 \mathrm{H}, \mathrm{m}), 7.44$ $(1 \mathrm{H}, \mathrm{d}, J=7.56 \mathrm{~Hz}), 7.26-7.32(3 \mathrm{H}, \mathrm{m}), 7.21-7.25$ $(2 \mathrm{H}, \mathrm{m}), 2.75-2.78(2 \mathrm{H}, \mathrm{m}), 2.51(2 \mathrm{H}, \mathrm{d}, J=6.68$ $\mathrm{Hz}), 2.24(6 \mathrm{H}, \mathrm{s}), 1.76-1.81(2 \mathrm{H}, \mathrm{m}), 1.26-1.43(3 \mathrm{H}$, m), 1.19-1.24 (2H, m); $\left.{ }^{13} \mathrm{C} \mathrm{NMR} \mathrm{(100} \mathrm{MHz,} \mathrm{CDCl}_{3}\right) \delta$ : $141.9,137.8,135.2,134.2,131.7,128.8,126.8,124.4$, 124.0, 123.0, 122.9, 119.2, 118.7, 113.6, 55.5, 46.1, 42.5, 36.9, 31.7, 9.5. ESI mass: $\mathrm{m} / \mathrm{e} 383.5(\mathrm{M}+\mathrm{H})^{+}$.

\section{Results and Discussion}

\section{$3.1 \quad 5-H T_{6} R$ receptor binding assay}

The in vitro $5-\mathrm{HT}_{6} \mathrm{R}$ binding assay of all targeted compounds, that is, Compounds I(9a-0) was carried out on human recombinant receptor expressed in HEK293 cells: Radioligand used was $\left[{ }^{3} \mathrm{H}\right]-\mathrm{LSD}(60-80$ $\mathrm{Ci} / \mathrm{mmol}$ ). Final ligand concentration was $1.5 \mathrm{nM}$, Nonspecific determinant was methiothepin mesylate- $[0.1$ $\mu \mathrm{M}]$; reference compound was methiothepin mesylate, positive control was methiothepin mesylate.

\subsection{Structure activity relationship (SAR)}

Most of the synthesized compounds have shown potent affinity towards $5-\mathrm{HT}_{6} \mathrm{R}$ by displacing the radioligand $\left[{ }^{3} \mathrm{H}\right]$-LSD when tested at $100 \mathrm{nM}$ concentration (table 1). By using unsubstituted indole, we initially synthesized 1-[3-[(1-methyl piperidin-4-yl) methyl] benzenesulfonyl]- $1 H$-indole, that is, compound 9a. This compound displayed a potent affinity with an inhibition of $97.49 \%$ towards $5-\mathrm{HT}_{6} \mathrm{R}$. We then introduced selective substitutions like methyl and methoxy at $\mathrm{R}^{2}$ position of Compounds $\mathbf{I}$ and synthesized $\mathbf{9 b}$ and $9 c$ respectively. These compounds were also found to have potent affinity towards $5-\mathrm{HT}_{6} \mathrm{R}$ with an inhibition of $98.65 \%$ and $92.14 \%$ respectively. Encouraged with these results and also to better understand the SAR of the series, we inserted various substitutions at $\mathrm{R}^{1}$ of indole and $\mathrm{R}^{2}$ was fixed as $\mathrm{H}$, methyl or methoxy and obtained the compounds (9d-9o). Compounds $9 \mathbf{d}-\mathbf{9 h}$ were achieved by introducing $-\mathrm{OCH}_{3}$ group at $4^{\text {th }}$ and $5^{\text {th }}$ position of indole and substitutions at $\mathrm{R}^{2}$ position was kept constant as discussed above. Among these, compounds 9d bearing a methoxy group $5^{\text {th }}$ position of indole core and $\mathbf{9 h}$ bearing a methoxy group at $4^{\text {th }}$ position of indole core have displayed an inhibition of $81.15 \%$ and $61.62 \%$ respectively towards $5-\mathrm{HT}_{6} \mathrm{R}$. The inhibitory potential of these compounds were lower when compared to unsubstituted parent compounds 9a-9c. A similar trend of reduction in affinity was observed for $9 \mathrm{e}\left(\mathrm{R}^{1}=5-\mathrm{OCH}_{3}, \mathrm{R}^{2}=-\mathrm{CH}_{3}\right.$, $50.54 \%), 9 f\left(\mathrm{R}^{1}=5-\mathrm{OCH}_{3}, \mathrm{R}^{2}=-\mathrm{OCH}_{3}, 83.49 \%\right)$ and $9 \mathrm{~g}\left(\mathrm{R}^{1}=4-\mathrm{OCH}_{3}, \mathrm{R}^{2}=-\mathrm{CH}_{3}, 75.68 \%\right)$, indicating that the introduction of electron donating groups on indole core could have diminishing effect on binding affinity towards $5-\mathrm{HT}_{6} \mathrm{R}$. The other substitutions evaluated include fluoro group at $5^{\text {th }}$ and $6^{\text {th }}$ positions $(9 \mathbf{i}-91)$ and methyl group at $3^{\text {rd }}$ position $(\mathbf{9 m}-\mathbf{9 o})$ of indole. Among fluoro substituted derivatives, compound $9 \mathbf{i}$ where $\mathrm{R}^{1}=$

Table 1. SAR data of Compounds $\mathbf{I}^{\mathbf{a}}$.

\begin{tabular}{|c|c|c|c|c|c|c|}
\hline \multirow[b]{2}{*}{ Compound } & \multirow[b]{2}{*}{$\mathbf{R}^{1}$} & \multirow[b]{2}{*}{$\mathbf{R}^{2}$} & \multirow{2}{*}{$\begin{array}{l}\% \text { inhibition at } h 5-H_{6} R \\
\text { at } 100 \mathrm{nM} \text { concentration } \\
\text { a, b }\end{array}$} & \multicolumn{3}{|c|}{ cAMP functional assay for $5-H^{-} T_{6} R^{c}$} \\
\hline & & & & $\overline{K_{\mathrm{b}}(n M)}$ & $\mathrm{IC}_{50}(n M)$ & $I_{\max }$ \\
\hline $9 \mathbf{a}$ & $\mathrm{H}$ & $\mathrm{H}$ & 97.49 & 2.78 & 5.75 & $100 \%$ \\
\hline 9b & $\mathrm{H}$ & $-\mathrm{OCH}_{3}$ & 98.65 & 0.8 & 11.80 & $99 \%$ \\
\hline 9c & $\mathrm{H}$ & $-\mathrm{CH}_{3}$ & 92.14 & & & \\
\hline 9d & $5-\mathrm{OCH}_{3}$ & $\mathrm{H}$ & 81.15 & & & \\
\hline $9 e$ & $5-\mathrm{OCH}_{3}$ & $-\mathrm{CH}_{3}$ & 56.54 & & & \\
\hline $9 f$ & $5-\mathrm{OCH}_{3}$ & $-\mathrm{OCH}_{3}$ & 83.49 & & & \\
\hline $9 \mathrm{~g}$ & $4-\mathrm{OCH}_{3}$ & $-\mathrm{CH}_{3}$ & 75.68 & & & \\
\hline $9 \mathrm{~h}$ & $4-\mathrm{OCH}_{3}$ & $\mathrm{H}$ & 61.62 & & & \\
\hline $9 \mathbf{i}$ & $5-\mathrm{F}$ & $\mathrm{H}$ & 82.35 & 2.6 & 6.12 & $98 \%$ \\
\hline $9 \mathbf{j}$ & $5-\mathrm{F}$ & $-\mathrm{CH}_{3}$ & 75.68 & & & \\
\hline $9 \mathbf{k}$ & $6-\mathrm{F}$ & $\mathrm{H}$ & 96.53 & & & \\
\hline 91 & $6-\mathrm{F}$ & $-\mathrm{CH}_{3}$ & 90.31 & & & \\
\hline $9 \mathrm{~m}$ & $3-\mathrm{CH}_{3}$ & $\mathrm{H}$ & 101 & 0.4 & 6.50 & $100 \%$ \\
\hline 9n & $3-\mathrm{CH}_{3}$ & $-\mathrm{CH}_{3}$ & 99.69 & 1.5 & 4.96 & $99 \%$ \\
\hline 90 & $3-\mathrm{CH}_{3}$ & $-\mathrm{OCH}_{3}$ & 100.54 & 0.9 & 12.80 & $99 \%$ \\
\hline
\end{tabular}

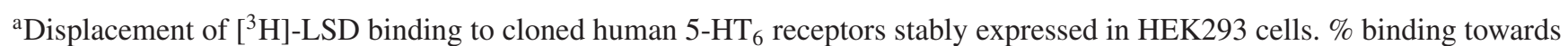
$5-\mathrm{HT}_{6} \mathrm{R}$ values were determined in duplicate and the average values are reported here.

${ }^{\mathrm{b}}$ The binding assays were carried out at Novascreen Biosciences Corporation, USA as per their standard protocol.

${ }^{\mathrm{c}} K_{\mathrm{b}}$ values were determined using non-radioactive cell based assay. $\mathrm{IC}_{50}$ and $I_{\max }$ values are the mean of two experiments. 
5-F, $\mathrm{R}^{2}=\mathrm{H}$ and $9 \mathbf{j}$ where $\mathrm{R}^{1}=5-\mathrm{F}, \mathrm{R}^{2}=-\mathrm{CH}_{3}$ have displayed an inhibition of $82.35 \%$ and $75.68 \%$ respectively towards $5-\mathrm{HT}_{6} \mathrm{R}$. The other compounds of the series, that is, $9 \mathbf{k}(96.53 \%)$ and $9 \mathrm{l}(90.31 \%)$ with $\mathrm{R}^{1}=$ 6-F displayed better affinity towards 5 - $\mathrm{HT}_{6} \mathrm{R}$ compared $9 \mathbf{i}$ and $9 \mathbf{j}$ respectively. In general, compounds bearing electron withdrawing substitution on indole core have displayed better affinity towards $5-\mathrm{HT}_{6} \mathrm{R}$ compared to electron donating groups, with the exception of 3-methyl substituted indole derivatives. Among all the synthesized derivatives, compounds $9 \mathrm{~m}\left(\mathrm{R}^{1}=3-\right.$ $\left.\mathrm{CH}_{3}, \mathrm{R}^{2}=\mathrm{H}, 101 \%\right), 9 n\left(\mathrm{R}^{1}=3-\mathrm{CH}_{3}, \mathrm{R}^{2}=-\mathrm{CH}_{3}\right.$, 99.69\%) and $90\left(\mathrm{R}^{1}=3-\mathrm{CH}_{3}, \mathrm{R}^{2}=-\mathrm{OCH}_{3}, 100.54 \%\right)$ were the most potent. From the above SAR, it could be observed that compounds bearing a methyl substitution at $3^{\text {rd }}$ position of indole nucleus are more preferable compared to compounds having substitutions at other positions of indole nucleus. In general, a series of Compounds I, was identified as a novel structural motif having potent $5-\mathrm{HT}_{6} \mathrm{R}$ binding affinity.

After achieving the compounds with potent affinity, our next aim was to investigate the antagonistic potential of the synthesized analogues of Compounds I towards $5-\mathrm{HT}_{6} \mathrm{R}$. For this purpose, few of the select compounds from the series were further evaluated for their functional activity at $5-\mathrm{HT}_{6} \mathrm{R}$ using non radioactive $\mathrm{CHO}$ based cell assay. ${ }^{15}$ A similar SAR trend was observed from the tested compounds as they showed full antagonistic activity by inhibiting the 5-HT stimulated cAMP accumulation as can be seen from the $\mathrm{IC}_{50}$ and $I_{\max }$ values (table 1).

A number of compounds which displayed excellent potency in both radioligand binding and cell based functional assay were further profiled for selectivity on a panel of closely related 5-HT receptors, histamine $\mathrm{H}_{1}$ and $\mathrm{H}_{3}$, dopamine $\mathrm{D}_{2}$ and $\mathrm{D}_{3}$, adrenergic $\alpha_{1 \mathrm{~B}}$, and the transporters like SERT, DAT and NET. Most of the compounds displayed 50-100 fold selectivity over all the receptors tested (data not shown) indicating limited side-effects due to unforeseen add-on therapies.

\subsection{Microsomal metabolic stability and pharmacokinetic study}

The potent compounds of the series, that is, $\mathbf{9 m}, \mathbf{9 n}$ and 9o were further evaluated for Cytochrome P450 liabilities, microsomal metabolic stability studies (table 2) and pharmacokinetic profile (table 3). Compounds $\mathbf{9 m}$ and $9 \mathrm{n}$ were moderately metabolized in human $(45 \%)$ and $(51 \%)$ respectively whereas compound 90 was extensively metabolized (85\%). These compounds were extensively metabolized in rat liver microsomes. Further evaluation of these compounds towards most
Table 2. Microsomal metabolic stability and Cytochrome P450 data of selected compounds ${ }^{\mathrm{a}}$.

\begin{tabular}{|c|c|c|c|c|}
\hline \multirow[b]{2}{*}{ Compound } & \multicolumn{2}{|c|}{$\mathbf{I C}_{\mathbf{5 0}}(\mu \mathbf{M})$} & \multicolumn{2}{|c|}{$\begin{array}{c}\text { Surrogate \% } \\
\text { metabolism in } \\
\text { liver microsomes }\end{array}$} \\
\hline & CYP 2D6 & CYP 3A4 & human & Wistar rat \\
\hline $9 \mathrm{~m}$ & 26.13 & 7.65 & 45 & 81 \\
\hline $9 n$ & 23.81 & 5.49 & 51 & 93 \\
\hline 90 & 31.81 & 2.56 & 85 & 98 \\
\hline
\end{tabular}

${ }^{\text {a The Cytochrome P450 inhibitory potential was determined }}$ using isoform selective assays using human liver microsomes. These values are the mean of duplicate determinations. Microsomal metabolic stability was performed at $30 \mathrm{~min}$ incubations in Wistar rat and Human $(2.5 \mu \mathrm{M})$.

common cytochrome P450 (CYPs) enzymes (2D6, 3A4) showed low ( $\mathrm{IC}_{50}>10 \mu \mathrm{M}$ towards CYP 2D6) to moderate inhibition $\left(\mathrm{IC}_{50}>2.5 \mu \mathrm{M}\right.$ towards CYP 3A4) indicating that the compounds from this series may have lower potential for drug-drug interaction in human, through the major metabolic enzymes in the liver.

Pharmacokinetic studies of select compounds were assessed in male wistar rats. Compound $\mathbf{9 m}$ at an oral dose of $10 \mathrm{mg} / \mathrm{kg}$ was rapidly absorbed in rats with a good $i v$ half-life of $3.24 \pm 1.82 \mathrm{~h}$ with an adequate oral bioavailability of $14 \pm 6 \%$. It had displayed $\mathrm{C}_{\max }=$ $153 \pm 41 \mathrm{ng} / \mathrm{mL}$ occurred at $\mathrm{T}_{\max } 0.83 \pm 0.29 \mathrm{~h}$. The oral exposure for this compound was found to be $390 \pm$ $61 \mathrm{ng} \mathrm{h} / \mathrm{mL}$. It had a clearance of $61 \pm 15 \mathrm{~mL} / \mathrm{min} / \mathrm{kg}$ with a volume of distribution of $19 \pm 14 \mathrm{~L} / \mathrm{kg}$ for $i v$ dose. The $\mathrm{C}_{\max }$ of compounds $9 \mathbf{n}$ and 90 were found

Table 3. Pharmacokinetic profile of selected compounds in male wistar rats. ${ }^{\mathrm{a}}$

\begin{tabular}{|c|c|c|c|}
\hline Compound & $9 \mathrm{~m}$ & $9 n$ & 90 \\
\hline \multicolumn{4}{|c|}{ Intravenous } \\
\hline dose $(\mathrm{mg} / \mathrm{kg})$ & 10 & 10 & 10 \\
\hline $\mathrm{t}_{1 / 2}(\mathrm{~h})$ & 3.241 .82 & $3.06 \pm 1.21$ & $1.70 \pm 0.22$ \\
\hline $\mathrm{Vz}(\mathrm{L} / \mathrm{kg})$ & $19.7 \pm 14$ & $22.6 \pm 7.8$ & $10.9 \pm 3.24$ \\
\hline \multicolumn{4}{|c|}{ Oral } \\
\hline dose $(\mathrm{mg} / \mathrm{kg})$ & 10 & 10 & 10 \\
\hline $\mathrm{C}_{\max }(\mathrm{ng} / \mathrm{mL})$ & $153 \pm 41$ & $72 \pm 24$ & $93 \pm 29$ \\
\hline $\mathrm{T}_{\max }(\mathrm{h})$ & $0.83 \pm 0.29$ & $0.83 \pm 0.29$ & $0.85 \pm 0.27$ \\
\hline $\mathrm{AUC}_{\mathrm{t}}(\mathrm{ng} \mathrm{h} / \mathrm{mL})$ & $390 \pm 61$ & $251 \pm 52$ & $285 \pm 61$ \\
\hline $\mathrm{F}(\%)$ & $14 \pm 6$ & $13 \pm 4$ & $12 \pm 2$ \\
\hline $\mathrm{C}_{\mathrm{b}} / \mathrm{C}_{\mathrm{p}}^{\mathrm{b}}$ & $2.05 \pm 0.12$ & $1.78 \pm 0.53$ & $0.42 \pm 0.07$ \\
\hline
\end{tabular}

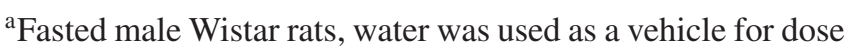
formulation preparation; $10 \mathrm{~mL} / \mathrm{kg}$ for oral and $2 \mathrm{~mL} / \mathrm{kg}$ for intravenous was used as dosing volume. Values are mean \pm $\mathrm{SD} ; \mathrm{N}=3$ animals/route.

${ }^{\mathrm{b}}$ Discrete brain penetration was performed in rats at 10 $\mathrm{mg} / \mathrm{kg}$ at $1 \mathrm{~h}$ after oral administration. 
to be $72 \pm 24 \mathrm{ng} / \mathrm{mL}$ and $93 \pm 29 \mathrm{ng} / \mathrm{mL}$ respectively. The oral bioavailability of compounds $9 \mathbf{n}$ and $\mathbf{9 o}$ were found to be $13 \pm 4$ and $12 \pm 2$ respectively. The high metabolism of these compounds in rats could be possible reason for high clearance. The compounds $\mathbf{9 m}$ and 9n have demonstrated an adequate brain penetration $\left(\mathrm{C}_{\mathrm{b}} / \mathrm{C}_{\mathrm{p}}\right)$ of $2.05 \pm 0.12$ and $1.78 \pm 0.53$ respectively. This selective partitioning of compounds into the brain would be one of important requirements for achieving in vivo activity against neuropsychiatric disorders.

\section{Conclusion}

We have identified a novel series of Compounds I, that is, [3-[(1-Methylpiperidin-4-yl) methyl] arylsulfonyl]$1 \mathrm{H}$-indole derivatives, obtained by migrating cyclic amine moiety from indole core to arylsulfonyl group on indole. This novel series of compounds reported here have potent in vitro binding affinities. Few of the selected compounds have displayed adequate brain penetration, acceptable selectivity and good overall Pharmacokinetic properties. Based on the above findings, the novel series of Compounds I, in general, was selected for further optimization and development in animal models for detailed efficacy studies.

\section{Supplementary Information}

The electronic supporting information can be seen at www.ias.ac.in/chemsci.

\section{Acknowledgements}

The support received from discovery analytical department and Mr. Venkateswarlu Jasti, CEO, Suven Life Sciences Ltd., Hyderabad is gratefully acknowledged.

\section{References}

1. Isensee K, Petroianu G and Stark H 2007 J. Appl. Biomed. 557

2. Johnson C N, Roland A and Upton N 2004 Drug Discov. Today: Therapeutic Strategies 113

3. Danysz W and Parsons C G 2003 Int. J. Geriatr. Psychiatry 18 Suppl 1: S23

4. Farlow M R and Cummings J L 2007 Am. J. Med. 120 388

5. Gerard C, Martres M P, Lefevre K, Miquel M C, Verge D, Lanfumey L, Doucet E, Hamon M and Mestikawy S E 1997 Brain Res. 746207

6. Dawson L A, Nguyen H Q and Li P 2001 Neuropsychopharmacology 25662

7. Glennon R A, Siripurapu U, Roth B L, Kolanos R, Bondarev M L, Sikazwe D, Lee M and Dukat M 2010 Curr. Top. Med. Chem. 10579

8. Maher-Edwards G, Zvartau-Hind M, Hunter A J, Gold M, Hopton G, Jacobs G, Davy M and Williams P 2010 Curr. Alzheimer. Res. 7374

9. Arnt J, Bang-Andersen B, Grayson B, Bymaster F P, Cohen M P, DeLapp N W, Giethlen B, Kreilgaard M, McKinzie D L, Neill J C, Nelson D L, Nielsen S M, Poulsen M N, Schaus J M and Witten L M 2010 Int. J. Neuropsychopharmacol. 131021

10. Tsai Y, Dukat M, Slassi A, MacLean N, Demchyshyn L and Savage J E et al. 2000 Bioorg. Med. Chem. Lett.10 2295

11. Nirogi R, Dwarampudi A, Kambhampati R, Bhatta V, Kota L, Shinde A, Badange R, Jayarajan P, Bhyrapuneni G and Dubey P K 2011 Bioorg. Med. Chem. Lett. 21 4577

12. Zhou P, Kelly MG and Li Y WO 2002051832

13. Lopez-Rodriguez ML, Bellinda B, Tania de la F, Arantxa S, Leonardo P and Mercedes C 2005 J. Med. Chem. 484216

14. (a) Clark R D and Repke D B 1984 Heterocycles 22 195; (b) Batcho A D and Leimgruber W 1985 Org. Synth. 63 214

15. Gonzalo R, Elisabeth S, Marta P, Pilar P, Xavier C, Jorg H, Helmut B and Petrus J P 2006 Br. J. Pharmacol. 148 1133 